\title{
DISTRO SEBAGAI PROVIDER GAYA HIDUP “ALTERNATIF”: MENENGOK STRATEGI DISTRO DALAM USAHANYA MEMPERTAHANKAN EKSISTENSI
}

\author{
Zakiyah Derajat \\ Program Studi Kajian Budaya dan Media \\ Sekolah Pascasarjana Universitas Gadjah Mada \\ Email: zakiyah.derajat@gmail.com
}

\begin{abstract}
Distro (distribution outlet/distribution store), with its DIY (Do-It-Yourself) and independent ethos, has ever been so popular in Yogyakarta as youth's field to express their self. Decade passed, youth changed, distro still exists, but now it is merely the "alternative" of the big (ie. mall). Descriptive qualitative research based on field ethnography within May and June 2013, I would discuss the strategy of Demangan distro area (Jl. Cendrawasih, Yogyakarta), in forming their nowadays identity in order to remain exist. The discussion shows that there are some of their stratregies: by converging in one area and structuring distro region, by interior design, and by not-that-indie (at all) identity. The lower number of distro and its attempt of forming its DIY-ethos-ed youth indicate that the youth are now, to a certain extent, not interested in producing and distributing. Hence, most of them are no more than the object of capitalism, which is by consuming.
\end{abstract}

Keywords: Distro, Youth, Indie, Capitalism, Brand.

\begin{abstract}
ABSTRAK
Distro (distribution outlet/distribution store) pernah merajai Yogyakartasebagai arena kaum muda mengekspresikan kediriannya dengan ideologi DIY-nya (do-it-your self) yang sangat kental dengan semangat kemandirian dan indie (independen). Dekade berlalu, kaum muda berubah, distro tetap hadir, tetapi menjadi benar-benar hanya "alternatif" dari yang besar (seperti mal). Penelitian kualitatif deskriptif berdasarkan etnografi lapangan selama Mei-Juni 2013, saya akan membahas strategi kawasan distro di kawasan Jl. Cendrawasih (Demangan), Yogyakarta, dalam membentuk identitas terkini-nya sehingga dapat tetap bertahan. Hasil pembahasan memperlihatkan beberapa strategi distro-distro tersebut, di antaranya: dengan berkumpul membentuk kawasan, melalui penataan ruang, dan diri yang tak lagi indie. Semakin surutnya jumlah distro dan kaderisasi muda-mudi beretos DIYdi dalamnya tidak membawa kabar baik karena ini berarti generasi muda tidak lagi tertarik dalam memproduksi dan menjual.Dengan demikian kini sebagian besar kaum tersebut hanyalah menjadi obyek kapitalisme semata, yaitu dengan mengkonsumsi.
\end{abstract}

Kata Kunci: Distro, Kaum Muda, Indie, Kapitalisme,Brand. 


\section{PENGANTAR}

Perjalanan menuju Ambarukmo Plasa, salah satu mal terbesar di Yogyakarta, saya melewati sebuah kawasan yang memiliki kesibukan serupa dengan bilik-bilik dalam mal tersebut. Sederet kawasan berisi toko menjual beberapa produk, kebanyakan berupa sandang. Lalu lalang pembeli, dengan beragam gayanya mengunjungi kawasan ini. Itulah kawasan distro di Demangan, areal di Jl. Affandi yang lebih akrab disebut Gejayan.

Mal yang telah menjadi kepanjangan tangan produsen paling ampuh, dengan menyediakan beragam brand untuk melengkapi hasrat gaya hidup konsumen, seakan mendapati kawannya. Distro menjadi salah satu dari provider gaya hidup "yang lain" tersebut, bersama dengan misalnya toko online, butik di pinggiran jalan, awul-awul, fenomena garage sale, dan lain-lain. Mereka kemudian menemukan titel "alternatif"nya: alternatif dari Mal yang sudah mapan. Terkait dengan kapital, penyedia gaya hidup di luar Mal memang terkesan kurang mapan bila dibandingkan dengan yang ada di Mal. Akan tetapi, kemudian hal ini dapat dibantah dengan banyaknya program Bank yang menawarkan kredit usaha. Artinya sebuah praktik distingsi hadir di sini, dari utamanya yang (terlihat) di luar mainstream.

Usaha distingsi menjadi penting dalam pembentukan sebuah identitas. Dalam kasus ini, provider gaya hidup "alternatif", harus membentuk kedirian untuk kelangsungan hidupnya di tengah-tengah maraknya provider "alternatif" yang lain, selain tentu harus tetap menjadi "alternatif" atas sesuatu yang masif seperti Mal. Konsep brand yang mereka tawarkan harus jelas, sehingga mereka sukses membangun identitas yang "paradoks"; dipandang cukup sama sebagai saingan, tetapi secara bersamaan juga harus berbeda sehingga dapat dipandang unik oleh konsumen (Kornberger, 2010: 27).

Salah satu hal yang akan dipaparkan dalam tulisan ini adalah usaha distingsi yang dilakukan oleh distro merupakan salah satu provider gaya hidup "alternatif". Distro menjadi menarik untuk dibahas karena perjalanan historisnya. Pada awal kehadirannya di tahun 90-an merupakan salah satu perlawanan kaum muda. Kemudian jumlahnya pernah meledak di tahun 2000-an. Kini pada dekade ketiga kehadirannya, ia seakan "meredup", seiring dengan mulai melunturnya semangat "perlawanan" yang ia (pernah) bawa. Akan tetapi, fakta bahwa ia masih dapat bertahan tentu tidak dapat dibiarkan lewat begitu saja.

Kawasan distro Demangan (tepatnya terletak di Jl. Cendrawasih) juga menawarkan cerita selanjutnya. Mailbox menjadi distro tertua yang berdiri di sini. Selama hampir satu dekade, Mailbox merajai Jl. Cendrawasih, pasalnya dalam kurun waktu mulai berdirinya (2002) hingga 2009, ia satu-satunya distro yang ada di kawasan tersebut. Hingga pada akhirnya 7 Souls (baca: Seven Souls) di tahun 2009 mendekat dan mendirikan tokonya sekitar 100 meter dari Mailbox. Kemudian di tahun yang sama Staircose juga hadir meramaikan. Lalu Crowd, Fusion, RSCH, dan beberapa distro lain hingga yang terakhir di tahun 2012, Nimco muncul melengkapi kompleks ini. Totalnya sekitar belasan distro berada di sini. Kawasan ini pun menjadi unik karena dari beberapa yang hingga kini bertahan di Yogya, distro-distro ini seakan memilih untuk berkelompok di areal tersebut, seolaholah tak ingin kesepian sendiri tanpa teman "seideologi". Kawasan inilah yang menjadi subyek penelitian lapangan saya.

Lebih dari itu, mengumpulnya beberapa distro yang selamat ini, kini dapat dipandang sebagai "the new emerging power" karena mampu menarik animo pengunjung yang cukup besar, bahkan menjadi salah satu tujuan alternatif pariwisata di Yogya.

Pertanyaan besar yang lalu muncul adalah "strategi apa (Certeau 1984) yang diusung distro dalam membentuk identitasnya sehingga tetap dapat bertahan?" Pertanyaan ini sekaligus ingin menelisik pergeseran makna produk yang distro bawa dan sekaligus gaya hidup yang kini ia tawarkan. 


\section{PEMBAHASAN}

Tubuh menjadi sarana untuk mengekspresikan kedirian. Bukan ia dapat berbuat apa yang dalam masyarakat kontemporer menjadi sangat penting, tetapi apa yang dapat ia suguhkan sebagai tontonan. Fenomena pamrih untuk ditonton ini mengafirmasi penuh tesis Debord dalam The Society of the Spectacle (1967), di mana tahap terakhir dari degradasi kehidupan manusia menemui masanya: appearance; menampilkan diri menjadi yang paling penting di atas segalanya (di atas being dan having). Pepatah "Don't judge the book by its cover" pun kini menemui ajalnya.

Pada tubuh sebagai display, fashion menjadi hal pertama yang paling mudah disuguhkan. Menurut Simmel (dalam Barker 2011: 143) bahwa "fashion merepresentasikan suatu aksi penyeimbangan antara individuasi dengan keseluruhan ke dalam kehidupan kolektif". Di satu sisi fashion menandai inklusi, sebuah keterhubungan dalam grup sosial tertentu, di sisi lain dapat menegaskan identitas seseorang.

Artinya diri dapat berbahasa melalui fashion (Hall 1997: 38). Kebutuhan untuk mengartikulasikan diri lewat fashion ini ditangkap oleh bisnis menjadi sebuah kewajiban untuk memproduksi. Bila produk fashion, misalnya pakaian, hadir untuk memenuhi kebutuhan, brand hadir memproduksi hasrat untuk memenuhi kebutuhan tersebut (Kornberger 2010: 8). Komodifikasi hasrat menjadi bisnis tersukses di era posmodern. Salah satunya iklan, menjadi yang utama yang mengonstruksi brand.

Brand menjadi alat handal yang menawarkan beragam identitas yang dapat dipilih untuk diri. Artikulasi diri lewat fashion, lebih subtil lagi dapat dimaknai sebagai artikulasi diri melalui brand. Seseorang yang mengenakan sepatu berlogo Nike, akan memiliki identitas yang berbeda dengan yang mengenakan sepatu berlogo Eiger. Sebut saja yang terakhir melekatkan identitas adventure dan nature pada penggunanya, sedang yang pertama melekatkan kesan sporty dan kelas yang lebih tinggi. Tentu pemaknaan ini sangat tergantung pada budaya saya sebagai yang memberi makna. Hal ini juga terjadi pada dikotomi identitas yang dibawa produk yang dijual di Mal dan di distro. Seorang yang memakai kaos yang dibeli di Planet Surf, outlet yang kebanyakan dapat dijumpai di Mal dan menjual produk yang kebanyakan impor, memakai merek Volcom misalnya, akan dipandang berbeda dengan seorang yang memakai kaos unkl347, brand lokal yang terkenal di seantero jagad perindie-an Indonesia.

Selain untukyang mengonsumsinya, brand juga menjadi acuan bagi si produsen dalam membentuk produk yang ia hadirkan. Celia Lury (2004) menyebutnya sebagai interface, jembatan yang menghubungkan produsen dan konsumen. Identitas brand harus terlebih dahulu mengikat seluk-beluk organisasi produsen, baik di pihak manajemen maupun pekerjanya, menubuh padanya sehingga apaapa yang dilakukan produsen terorganisir dengan satu konsep brand tersebut. Artinya sebelum menghasilkan gaya hidup bagi konsumen, brand harus sudah kuat menjadi sebuah budaya bagi si produsen (Kornberger 2010: 116-117). Sebagai jembatan, brand memungkinkan produsen berkomunikasi dengan konsumen, dan tentu konsumen berkomunikasi dengan produsen.Timbal balik ini berdampak pada inovasi $b r a n d$.

\section{Brand Independen dan Kemunculan Distro (di Indonesia)}

Dimulai awal tahun 90-an, subkultur anak muda Indonesia terangkum dalam musik independen yang saat itu lebih dikenal dengan istilah underground. Munculnya band-band underground ini tak terlepas dari demam musik trash metal, gaya musik yang lebih ekstrem dari heavy metal, yang melanda dunia di akhir 80-an. Musik inilah yang kemudian menginspirasi anak muda dalam negeri untuk membuat aliran underground versi mereka.

Dalam bermusik underground, konsep DIY, Do-It-Yourself sudah mereka gunakan. Label mereka tidak terkait dengan yang 
major, menggunakan kekuatan sendiri, aturan sendiri, dan terkesan bebas dalam bertindak. Do-It-Yourself juga digunakan dalam membuat merchandise mereka. Penampilannya punk, bila tidak berpotongan rambut Mohawk, maka gundul atau rambut panjang menjadi pilihan. Zaman pun berubah. Di tahun 2000-an gaya-gaya ekstrim baru kaum muda semakin banyak bermunculan, yang termanifestasi dalam berbagai penampilan fashion, mulai dari yang indie rock (berkaos produksi sendiri, celana bagian bawah dikecilkan mirip emo, emo itu sendiri, kadang bertato, dan lainlain - lebih "soft" daripada punk), hingga mod (dengan model fashion seperti The Beatles dan The Rolling Stones), hingga yang tidak nge-rocksama sekali (berkemeja, memakai kacamata bening normal, dll.), juga hingga hip-hop (ditandai dengan setelan yang dipakai kedodoran dan beraksesoris topi). Musik kaum mudanya pun turut beragam, tidak hanya underground metal (Luvaas 2009, 6). Independen, yang sering disingkat sebagai indie, kemudian mengambil alih popularitas kata underground.

Di tahun 1993, beberapa fans musik fanatik mendirikan studio musik di Bandung: Reverse. Tak hanya sebagai studio, tempat ini merupakan salah satu yang pertama yang menjual merchandise band indie internasional dan lokal. Mereka menjual T-shirt, jaket, kaset, dan poster. Inilah pioner distro di Indonesia.

Dendy Darmawan, salah satu pendiri distro 347 - kini unkl347, salah satu distro pertama dan yang sangat terkenal dari Bandung - mengaku di tahun 1996 mendesain T-shirt hanya untuk iseng-iseng saja. Ia dan teman-temannya, yang sering menyusuri pantai Jawa Barat untuk menemukan spot berselancar, tertarik untuk meniru model surf dan streetwear brand yang sudah mapan (dan impor) seperti Rusty dan Volcom. Mereka menjual barang yang mereka produksi setelah tahu dengan menjualnya dapat membantu biaya hobi ekspedisi berselancar mereka. Akhirnya ketika krisis moneter melanda di tahun 1997, Dendy, dkk.tak lagi mampu membeli barang-barang branded. DIY pun menjadi solusi (Luvaas 2013: 133-134).
Makna distro sendiri sudah dibahas oleh Luvaas dalam Pendahuluan disertasinya Generation DIY: Youth, Class, and the Culture of Indie Production in Digital-Age Indonesia (2009). Menurutnya distro merupakan singkatan dari distribution outlet, istilah yang pada mulanya dipakai untuk menjelaskan kumpulan komunitas atau distributor dari "zines" (majalah yang diproduksi terbatas dan diterbitkan sendiri) di AS dan Eropa. Ia melanjutkan bahwa di Indonesia, distro menjadi sangat beragam. Dari toko kecil penuh tempelan sticker, hingga yang menyerupai butik kelas atas dengan interior yang mewah. Dari yang dijalankan seperti normalnya bisnis (dengan staf permanen dan yang dikontrak), hingga yang hanya seperti komunitas. Bagaimanapun, mereka berbagi satu pendekatan yang sama, yang merupakan inti dari usaha ini: DIY ethos.

DIY (Do-It-Yourself) ia artikan sebagai " a network of youth throughout the island nation, who use new media technologies, pirated software, and an arsenal of copy machines and silkscreens to create their own magazines, clothing lines, and record labels outside commercial channels of production and distribution". Dengan demikian DIY gerakan muda indie Indonesia memiliki tiga kata kunci: teknologi media baru (jaringan internet), software bajakan, mesin fotokopi dan sablon.

Dengan adanya internet, mereka dimudahkan untuk mendapat sebuah gambar yang diinginkan yang sesuai "ide". Melalui komputer (yang dipakai bersama), dengan software bajakan seperti Corel Draw atau pun Photoshop, mereka mengeditnya, menjadi sesuatu yang tampak baru. Keberadaan mesin fotokopi memudahkan proses mengedit, dan teknologi sablon membuat semua hal dimungkinkan untuk dicetak di atas kaos polos. Dari sini mereka dapat memproduksi fashion yang mereka butuhkan, membuat brand indie mereka sendiri.

Tentang desain clothing ini, Luvaas memikirkan ulang konsep brikolase LeviStrauss. Ia menggunakan istilah " $c u t$ ' $n$ ' paste" yang dipakai desainer indie ketika mengedit. 
Desainer berlabel distro tersebut mengolah kembali segala "inspirasi" yang ia dapatkan dari internet, dari produk-produk global, menyesuaikan produk tersebut untuk audiens lokal yang "anti-komersil".

Proses pembentukan clothing lokal merupakan proses ketika konsumen kreatif seperti Dendy mulai membuat produknya. DeCerteau (1984: xiii-xiv) menyatakan bahwa users membuat berbagai macam perubahan ketika mereka mengonsumsi agar sesuai dengan minat dan aturan masing-masing. De Certeau pun memberi label "taktik" bagi apa yang dilakukan konsumen ini terhadap produk yang ia konsumsi. Kreativitas konsumen ini yang oleh Kornberger (2010: 133) disebut sebagai aktivitas yang produktif. Maka apa yang komunitas indie lakukan dengan memproduksi barang versi lokal, atau versi lebih dapat dijangkau dari suatu produk branded merupakan praktik konsumsi produktif.

Hal serupa lalu diabstraksikan oleh Luvaas sebagai DIY ethos, yang merupakan suatu keinginan untuk berpartisipasi aktif dalam memproduksi sebuah budaya, untuk berkontribusi terhadap bentuk, rupa, dan nilai-nilai yang dibawa budaya populer, daripada hanya tunduk mengonsumsinya (Luvaas 2009: 22) merupakan sebuah pendirian yang muncul dari ekspresi individu dan kapitalisme berkelompok. Perjalanan sejak mulainya Dendy membuat produknya sendiri hingga kini menjadi suatu gerakan berdasarkan konsep DIY ethos Luvaas tersebut merupakan sebuah perjalanan transformasi: dari mereka si pengguna taktik, menjadi mereka yang memiliki strategi (Certeau 1984: xix).

\section{Distro dan Kapitalisme}

Dendy Darmawan, dan mereka yang membangun distro atau outlet-outlet produksi independen pertama di Indonesia, merupakan pemain kunci dalam indie scene di negara ini. Luvaas mendemonstrasikan bahwa praktik-praktik entrepeneural mereka pasti berhubungan dengan ekonomi Indonesia serta kemunculan budaya neoliberal, terlebih setelah runtuhnya pemerintahan Soeharto. Walau demikian, hal ini bukan merupakan penyerahan diri setotal-totalnya pada rezim kapitalis tingkat lanjut yang termanifestasi dalam usaha transnasional dan multinational corporation (atau yang terlihat mata dengan korporasikorporasi besar), tetapi merupakan upaya mengolah kembali logika dan nilai-nilainya. Kalangan kelas menengah muda Indonesia, tidak hanya merupakan roda penggerak mesin kapitalis, mereka berada di antara roda tersebut, ikut serta menjalankan dan menyetir arahnya (2009: 49).

Maka tesis besarnya menjabarkan bagaimana distro dan gerakan indie yang mendasarinya, menjadi suatu upaya dari generasi muda Indonesia untuk turut "menyetir" kapitalisme-bukan melawannya. Luvaas menolak konsep "the end of history"nya Fukuyama yang meramalkan bahwa seluruh dunia akan berakhir pada demokrasi liberal dengan ekonomi pasar bebasnya (dalam Appignanesi et. al. 1997: 165-167). Ia menyebutkan bahwa anak muda Indonesia, melalui fenomena distro ini, sedang turut serta dalam membentuk wajah baru sejarah late capitalism (atau seperti istilah yang lebih banyak ia pilih: neoliberalisme).

"Neoliberalism is not the end-game of capitalism.
It's beginning to look more like a botched social
experiment than an inevitable outcome of our
economic course. There will be history beyond it,
just as there was history before it. And the youth
involved in the Indonesian indie scene want to be
part of determining the course that history takes."

Salah satunya dengan yang telah disebutkan sebelumnya, yaitu dengan kapitalisme berkelompok. Mereka adalah kumpulan kapitalis muda, dan gerakan DIY kaum muda merupakan sebuah arena produksi kultural yang memiliki habitus tertentu (Bourdieu 2010 (1993): xx). Mereka belajar membuat fashion mereka sendiri, dan nantinya menjual produk yang mereka hasilkan.

Kapitalisme yang dimaksud Fukuyama bukanlah akhir sejarah dunia, tetapi masih 
berkembang untuk mendapatkan posisi paling ideal bagi budaya masyarakat yang bersangkutan. Ide besar ini, dengan subyek generasi indie dan DIY yang saat itu (20062007) banyak terangkum dalam distro, Luvaas tuangkan dalam lima bab disertasinya.

\section{Menyelami Strategi Si “Alternatif”}

Certeau membahasakan strategi sebagai perhitungan daya-relasi yang menjadi mungkin ketika subyek berkuasa tersebut menciptakan ruang yang terisolasi dari lingkungannya. Ruang ini menjadi tempat untuk artikulasi dirinya untuk membangun kediriannya, sehingga tercipta hubungan dengan pesaing, musuh, klien, "target", dan lain-lain (1984: xix).

Sedang taktik, lebih digunakan oleh mereka yang tak dapat menciptakan ruang tersebut, dan karenanya lebih memenangkan waktu (sedang yang berkuasa, yang mengaplikasikan strategi, memenangkan ruang). Mereka yang menggunakan taktik selalu memperhatikan kesempatan. Begitu ia memenangkannya, tak bakal dapat dipertahankan selamanya. Selalu, kaum pengguna taktik yang disebut Certau sebagai "yang lemah" ini, harus memanipulasi kejadian-kejadian dan mengubahnya menjadi "kesempatan". Kejadian konsumsi sehari-hari banyak menggunakan taktik.

Distro, ataupun yang di sebut sebagai provider gaya hidup, dalam hal ini retailerretailer fashion, menggunakan strategi dalam usahanya berhadapan dengan sesamanya - pesaingnya. Beberapa bahasan saya akan banyak menyinggung konsep arena Bourdieu (saya melihat lingkungan retailer sebagai arena). Pengertian arena sebagai berikut:

"... suatu sistem posisi sosial yang terstruktur -yang dikuasai oleh individu atau institusisuatu inti yang mendefinisikan situasi untuk mereka anut.... Posisinya ada dalam relasinya dengan dominasi, subordinasi atau ekuivalensi (homologi) satu sama lain karena akses yan dapat mereka raih atas benda atau sumber (modal/(kapital)) yang dipertaruhkan di arena." (Jenkins 2004: 125)
Macam kapital tersebut di antaranya kapital kultural merupakan akumulasi pengetahuan yang memberikan kekuasaan dan status, contohnya pendidikan. Kemudian kapital ekonomi yaitu kekayaan. Kapital sosial mudahnya merupakan siapa yang dikenal (Barker 2011: 360).

Satu lagi adalah kapital simbolik, yang bersama modal kultural menjadi modal sangat penting dalam arena produksi kultural. Kapital simbolik sendiri, "mengacu pada derajat akumulasi prestise, ketersohoran, konskekrasi atau kehormatan, dan dibangun di atas dialektika pengetahuan (connaissance) dan pengenalan (reconnaissance)" (Bourdieu, 2010 (1993): xix).

\section{Berkumpul}

Mungkin kalimat saya di bagian Pendahuluan ("seolah-olah tak ingin kesepian sendiri tanpa teman "seideologi") bisa dikatakan terlalu berlebihan. Pasalnya kawasan ini tidak semudah itu ada; tidak pula direncanakan untuk menjadi kawasan Distro. 7 Souls yang memioneri merapat ke Mailbox pada 2009, tidak dengan tiba-tiba membangun distronya. Mas Slamet, yang "membawahi" tiga distro di sana, Fusion, 7 Souls, dan RSCH, menceritakan histori ini pada saya. Ia sendiri tidak suka diberi label manajer atau label posisi yang menurutnya sangat formal dan hirarkis. Ketiga distro tersebut di bawah payung kekeluargaan yang "biar santai, Mbak. Kerja enak, mau ngomongin ini itu juga enak.."

Mas Slamet, beserta owner ketiga distro tersebut (yang tidak terakses karena tidak ingin identitasnya diketahui banyak orang), dapat dikatakan memiliki mata bisnis yang jeli. Jalan Cendrawasih adalah jalan yang ramai dilalui para pengguna kendaraan bermotor. Jalan ini merupakan jalan alternatif terakhir untuk menghindari kemacetan di sekitar lampu merah pertemuan Jl. Affandi (Gejayan) dan Jalan Solo (Jl. Laks. Adisucipto), di mana Pasar Demangan yang sibuk berada. Mereka yang dari utara, dari UGM dan UNY misalnya, akan cenderung memilih jalan ini jika ingin pergi ke Jalan 
Solo (Jl. Laks. Adisucipto) demi Ambarukmo Plaza, Gedung Wanitatama, UIN, atau pun JEC yang nun jauh di Banguntapan sana.

Yang lalu menjadi masalah adalah keberadaan Mailbox. Mas Slamet bercerita bagaimana ia dan kawan-kawan sempat "was-was" ketika ingin membuka 7 Souls di kawasan tersebut. Mailbox berdiri di atas tanah sendiri, dan "orang tuanya tentara". Satu "manajemen"-nya pun akhirnya memberanikan diri mengontrak bangunan yang berada sekitar seratus meter dari Mailbox. Di masa di mana distro-distro mulai kelimpungan (sekitar tahun 2009), 7 Souls berhasil tetap bertahan. Berhasil juga tak dapati "pengusiran" dari Mailbox. Kesuksesan berdirinya lalu diikuti oleh rekan-rekan distro lainnya, termasuk juga diikuti dengan pembukaan cabang distro saudaranya, Fusion, dan saudara paling mudanya, RSCH.

Kawasan ini semakin ramai dan semakin banyak dikunjungi muda-mudi. Hingga kini, empat tahun setelah usaha pertama mendekatnya 7 Souls ke Mailbox, areal ini menjadi salah satu tujuan pariwisata Yogya. Banyak wisatawan domestik, terutama mereka yang sedang liburan sekolah, mengunjunginya. Maka distro yang tak begitu kuat brand-nya, dapat meraih energinya di sini. Mereka yang kuat yang tak terangkum di dalamnya, seperti Slackers, salah satu distro tertua di Yogya yang terletak di sekitar Maguwoharjo dan terkenal dengan komunitasnya, bisa jadi sedikit terusik dengan kehadiran "the new emerging power" ini. Slackers terkenal cukup idealis dengan tidak terlalu mementingkan uang (Luvaas 2009: 88). Bila ketenarannya, kapital simboliknya sedang mendapati tantangan, dapat jadi berpengaruh besar terhadap pendapatan mereka.

Dari sini, seakan terdapat sebuah fenomena pergeseran makna sukses sebuah distro. Slackers berhasil mendapat kapital simbolik yang besar dari menghidupi komunitasnya dan juga idealismenya. Demikian juga Unkl347 di Bandung (Luvaas 2009: 85).Di tahun 2000-an, komunitas menjadi tolak ukur utama kesuksesan sebuah distro. Label "falsu" (palsu), disematkan pada mereka yang tidak turut serta/ memiliki komunitas dan mementingkan profit daripada terlibat dalam gerakan indie.Distro-distro "falsu" banyak bertebaran pada saat itu. Pemberian label ini merupakan suatu indikasi di mana yang memberi label (si "idealis") lebih berkuasa dari yang diberi label (si "falsu"). Akhirnya yang "idealis" memiliki prestise yang lebih daripada yang palsu. Prestise ini ditangkap oleh kaum muda dengan bergabung menjadi salah satu komunitasnya. Akhirnya si "idealis" yang sukses.

Distro kawasan Demangan, bila mengikuti label yang dirumuskan oleh si "idealis" tersebut, termasuk ke dalam distro "falsu", tak terkecuali Mailbox.Tak ada dari mereka yang strict pada konsep komunitas indie.Namun kini, tak lagi terlihat bagaimana para "falsu" ini menjadi inferior dari yang "idealis". Malah, mereka seakan menggenapkan ke-"falsu"-an tersebut dengan berkumpul. Seakan dalam arena perdistroan ini, "idealisme" berbentuk komunitas indie, dijawab dengan "falsuisme", yang berbentuk komunitas juga: komunitas "falsu".

Idealisme komunitas indie tak lagi dianggap sebuah makna sukses sebuah distro. Sekarang kaum muda pun mau mengonsumsi si "falsu". Mudahnya kedua dari mereka sudah tak lagi penting bagi kebanyakan kaum muda. Pergeseran perspektif ini saya sinyalir karena kemunculan berjibunnya ruang artikulasi kedirian anak muda yang lain akhir-akhir ini, seperti Korean Pop, komunitas fotografi, komunitas travelling (dan backpacker), awul-awul, garage sale, onlineshop, dan lain-lain. Berkumpulnya distrodistro " falsu" ini akhirnya juga berarti sebuah usaha untuk berteriak "Kami masih ada!!!", kepada publik yang dewasa ini semakin dicekoki oleh berbagai macam gaya hidup.

\section{Desain Ruang}

"Mari silahkan, ada yang bisa saya bantu..!!", serempak dua gadis muda penjaga toko distro Nimco menyambut saya tepat 
ketika riuh Jl. Cendrawasih sudah tak lagi terdengar, tanda bahwa pintu kaca yang baru saja saya lewati telah tertutup dengan sempurna. Saya menjawab dengan senyum dan melangkahkan kaki lagi untuk melihat seisi distro ini.

Ruangannya yang dapat dikatakan sangat luas, menangguhkan bayangan saya tentang kebanyakan distro yang biasanya saya tahu, yaitu yang paling besar yang pernah saya temui, seluas ruang kelas berkapasitas empat puluhan orang. Bila distro yang ada di kepala saya seluas ruang tamu, Nimco adalah rumah bagi ruang tamu tersebut. Bangunannya sendiri dulunya merupakan kos-kosan. Manajemen memutuskan merombak desain beberapa titiknya, dan memakai beberapa yang lama yang kiranya dapat disesuaikan dengan kebutuhan. Salah satu yang lama yang masih dapat terlihat wujudnya, kini menjadi bilik-bilik berisi produk distro lain. Selain menjual brandclothing-nya, Nimco memang juga menjual ruang. Yang dahulunya kamarkamar, kini telah dirombak menjadi toko, dan disewakan kepada mereka pemilik brand yang berminat. Inilah toko di dalam toko.

Menurut Andre, si manajer penjualan dan operasional, desain Nimco berkonsep modern-vintage, sedang yang tertangkap di benak saya hanyalah kesan comfy. Aksen kayu mewarnai lantai dan display, dipasang tak beraturan tetapi membentuk motif yang menyenangkan. Aksen coklat muda dari kayu ini (yang disebut Andre sebagai vintage) dikombinasikan dengan warna putih yang didapat dari lampu yang tersebar di beberapa titik, dan cat di beberapa dindingnya, juga di beberapa atapnya. Mungkin hal terakhir ini yang menjadi referensi "modern" si manajer. Suasana benderang, AC yang sejuk, serta musik indie yang sedang mengalun menyertai, membuat saya ingin duduk di suatu sudut dan membaca, atau hanya menikmati lalu-lalang kesibukan yang ada dalam distro ini.

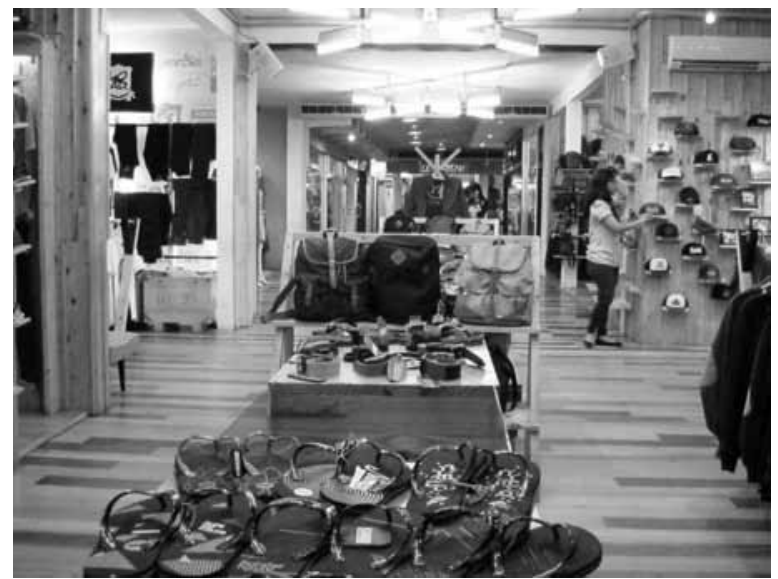

Gambar 1. Nimco dari depan - modern-vintage (foto: koleksi pribadi).

Rupanya apa yang saya bayangkan sudah pula dibaca oleh Nimco. Di lorong lebar di depan bilik-bilik yang ia sewakan tadi, telah disediakan beberapa meja dan kursi yang cocok sebagai tempat mengobrol. Dari Imam, manajer toko Nimco, saya dapati informasi bahwa di tempat meja dan kursi ini berada, kelak akan dibangun café mini. Konsep distro dan café, serta toko di dalam toko milik Nimco, seakan "terinspirasi" oleh 7 Souls, di mana terdapat toko juga di dalamnya (hanya berjumlah tiga), dan sudah terintegrasi satu café di salah satu bagian bangunannya.

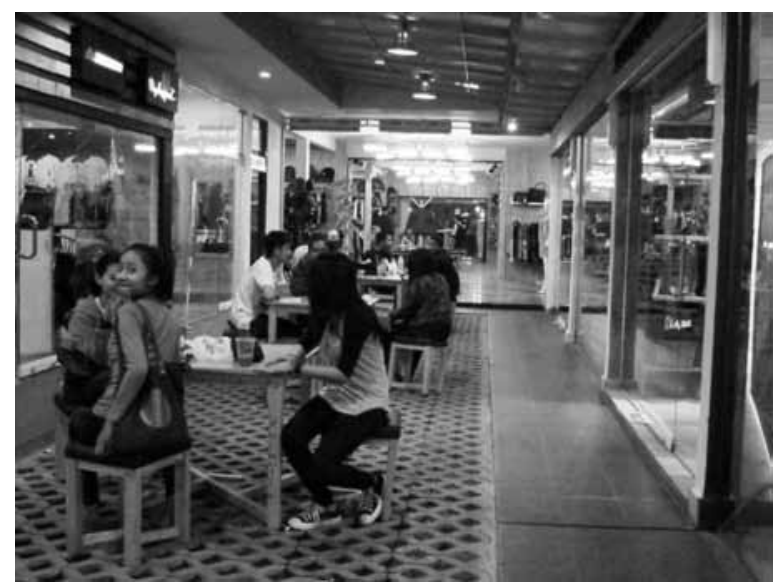

Gambar 2. Nimco dari belakang, dengan meja dan kursi (foto: koleksi pribadi).

Akan tetapi, fenomena ini bukan lagi merupakan hal yang unik sehingga tak dapat dikatakan siapa yang meniru siapa. Toko 
buku dan perpustakaan dilengkapi dengan sofa dan bahkan kini banyak perpustakaan yang memperbolehkan pengunjungnya makan di dalamnya. Juga konsep ruang kerja yang senyaman di rumah sedang ramairamainya digalakkan akhir-akhir ini.Dalam hal bisnis retailer, intinya terletak pada bagaimana membuat pelanggan nyaman. Maka desain interior yang nyaman akan membawa pelanggan untuk berlama-lama di dalam toko, dan tak lupa kata mereka yang di dunia bisnis: "the longer people stay in a store, the more money they will probably spend" (Underhill dalam Cooper et.all 2005: 154). Walau uang sangat penting, tetapi ada lagi yang didapat dari usaha tersebut, yaitu kapital sosial.

Bila melihat fenomena yang terjadi, desain interior yang homy merupakan sebuah strategi yang dilakukan untuk menghadapi "lawannya" yang lebih kuat. Sebut saja desain interior Mal tak perlu dibuat senyaman di rumah (walau ada bilik-bilik di Mal yang "senyaman di rumah", tetapi hanya beberapa saja yang memakai konsep ini). Mal menyediakan logikanya sendiri di mana retailer-retailer dari berbagai macam produk berkumpul, dari kebutuhan, fashion, hingga restoran. Kompleks ini sudah hadir dengan logika "rekreasi" belanja yang tentu akan menyerap banyak pengunjung. Menyaingi logika Mal untuk menghadirkan kompleks belanja yang begitu besar tentu tak mungkin, sehingga untuk dapat menarik pelanggan, konsep toko yang homy ini menjadi salah satu pilihan yang tepat.

\section{Diri yang Liminal}

Duduk mengobrol dengan Andre di kursi dan meja yang telah disediakan toko, ia menjelaskan konsep desain fashion yang diusung Nimco. "Yang populer aja, Mbak", katanya sembari membenarkan kacamata besarnya. Nge-pop berarti merangkum semua kalangan. Mereka yang tidak di scene indie tidak akan merasa aneh bila memakai desain Nimco. Saya tak kuasa untuk tidak mengecek brand Nimco sendiri. Produknya berbagai macam, dari kemeja, kaos, tas, hingga sepatu, yang diletakkan di display ruang utama. Brand ini juga merangkum produk perempuan.

Saya lalu berhenti pada sebuah baju penuh warna yang segera membuat saya mencari label brand-nya, memastikan itu bukan produk toko ini. Akan tetapi, tertulis "Nimco". Saya sedikit terkejut, karena walaupun Andre telah mengatakan konsep Nimco adalah pop, saya tak menyangka itu akan berarti se-ngepop-ngepop-nya. Baju berwarna-warni tersebut sangat mudah dijumpai di mal, bahkan baju di sebelahnya, yang berwarna pink dengan aksen brokat di bagian atasnya, dapat dibeli di Sunday Morning UGM, atau di garage sale dengan harga yang lebih murah.Desain kemeja dan kaosnya pun, menurut saya "nggak distro banget". Hanya dicantumkan brand Nimco kecil begitu saja, misal di kaos berkerah berwarna abu-abu.

Akan tetapi, Andre menjelaskan bahwa Nimco tidak bisa (mau) seidealis itu. Lewat beberapa penjaga tokonya, ia tahu desain mana saja yang disukai pelanggan. "Pernah kita desain satu yang menurut kita bagus, tapi sek, sek, (sebentar, sebentar) tunggu dulu. Consumer kita biasanya nggak suka desain yang menurut kita bagus itu.Jadi desain kayak gitu gak kepake", akunya.

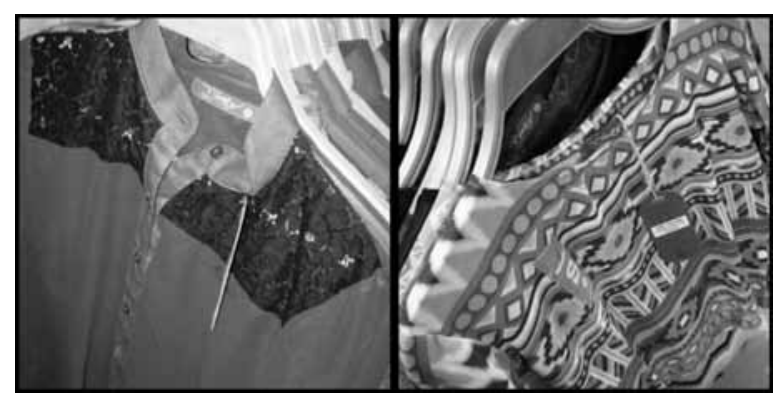

Gambar 3. Desain yang mudah ditemui di banyak jenis bisnis retail lainnya (foto: koleksi pribadi).

Nimco rupanya juga mengikuti trend pinjaman modal dari bank. Untuk mengontrak tanahnya selama lima tahun saja, Andre menyebut jumlah satu milyar dari bank. Betapa strategi kapital yang ia gunakan juga sangat mainstream.

Bagi Bourdieu (2010 (1993): xx), “... untuk mengikuti permainan di dalamnya (sebuah 
arena), harus memiliki habitus tertentu bukan habitus yang lain - yang harus dimiliki siapa punyang ingin memasuki arena tersebut, permainan tersebut." Beruntung Nimco seakan sadar dia bisa keluar dari permainan ini jika wajahnya sebegitu mainstream dan tidak mengikuti habitus indie di atas mana platform bisnisnya berjalan. Maka habitus itu ia terapkan, walau tidak lewat desain dan "berdikari"-nya, tetapi lewat "pernik" yang menghiasi distro tersebut.

Sebut saja pilihan musik yang masih ia putar adalah band-band indie, walau anehnya dalam tujuh hari seminggu, dua hari di antaranya Nimco memutar musik label mayor yang masih "nyambung" dengan distro (Andre mencontohkan BritPop seperti Coldplay dan Oasis). Juga, Nimco menjadwalkan minimal tiga kali setahun diadakan acara yang meng-"endorse"bandband indie, atau komunitas skate, di teras distronya yang luas.

Bila dilihat lebih seksama lagi, memang diri sesuatu yang liminal akan membawa kesimpulan "aneh" di benak pengamatnya. Akan tetapi, strategi liminal ini mereka pakai untuk tetap bertahan. Identitas brand Nimco boleh jadi tidak begitu "paradoks", yang unik berbeda, tetapi secara bersamaan juga diterima oleh khalayak. Nimco justru diterima karena dirinya yang "paradoks", "pura-pura" indie, tetapi sejatinya mainstream jua.

Sebuah Konklusi: Lelah dengan Indie vs. Mainstream hingga tiba pada pertanyaan di awal tentang gaya hidup apa yang kini distro tawarkan, setelah mengetahui bahwa produk yang ia bawa rupanya mudah dijumpai juga di mal-mal, atau di provider gaya hidup "alternatif" yang lain. Salah satunya dari desain. Teman-teman indie masih mendesain dengan konsep Posmonya yang dikatakan Luvaas sebagai "cut' $n$ ' paste". Jika rujukan yang indie adalah berbagai macam simbol di internet, memprosesnya hingga menjadi sebuah produk yang unik, korporasi besar terlihat juga menghasilkan produk yang tidak begitu berbeda dengan apa yang dihasilkan DIY-ers tersebut, entah dengan cara bagaimana. Maka ada hubungan dialektis antara keduanya sehingga produk semacam yang ada di distro pun mudah untuk ditemukan di Mal. Pernyataan Mas Slamet berikut akan memberi gambaran:

"Nggak ada lagi itu Mbak, indie.Indie dibilang indie kan seharusnya gak ngejar materi?"

Ia sadar betul yang dilakukannya adalah bisnis, dan yang dapat mengelola bisnis ini dengan terampil lah yang menang, tak pandang bulu harus berafiliasi dengan komunitas indie atau tidak. Maka apa yang mereka lakukan hanya seakan "pura-pura indie saja". Akhirnya secara substansial, bukan lagi gaya hidup indie dengan konsep DIY ethos yang kini ditawarkan oleh distrodistro ini.

"there is no indie vs. mainstream, no solid barrier between the commercial and the anti-commercial. There is only the subtle shifting of differently situated players in an on going game of social positioning. Everyone wants to be different. Everyone wants to stand out." (Luvaas 2009: 261)

Lalu ruang lah yang menjadi si "alternatif" tersebut. Brand distro dalam penelitian ini tidak hanya dapat dipandang terikat pada produk fashion yang ia (hasilkan dan) jual saja. Kawasan Demangan pun kini menjadi suatu brand.Mengonsumsi produk milik distro mana tak lagi penting. Yang lebih penting adalah bagaimana menyalurkan 'desire' yang telah dibentuk oleh brand (yang berupa) kawasan ini. Ia menawarkan penagalaman baru untuk "mencari" fashion,yang konon "unik" (dan produksi mereka yang muda), di sebuah kawasan yang baru pula.

\section{SIMPULAN}

Distro kini sedang berjuang untuk tetap bertahan atas kehadiran provider "alternatif" yang lain, yang saat ini menjamur dalam bentuk online maupun dalam bentuk butikbutik di pinggir jalan. Kebanyakan dari pesaing distro iniadalah retailer produk impor dari Korea dan Cina. Belum lagi habitus yang terangkum dalam DIY-ethos seakan mulai 
mengendur karena para agen di dalamnya terlihat sedang kegandrungan dengan produk-produk gadget elektronik, dan juga karena merebaknya arena aktualisasi diri yang lain. Maka setelah sempat kaum muda dikatakan turut menyetir arah neoliberalisme (Luvaas 2009: 49), sekarang mereka terlempar dari kemudi, santai menjadi penumpang menikmati perjalanan dengan mengonsumsi tanpa (mau) tahu akan dibawa ke mana.

\section{DAFTAR PUSTAKA}

Appignanesi, R., Garrat, C., Sardar, Z., Curry, P. 1997. Postmodernism for Beginners. Bandung: Penerbit Mizan.

Barker, Chris. 2011. Cultural Studies: Teori \& Praktik. Bantul: Kreasi Wacana.

Bourdieu, Pierre. 2010 (1993).Arena Produksi Kultural: Sebuah Kajian Sosiologi Budaya. Bantul: Kreasi Wacana.

Certeau, Michel De. 1984. The Practice of Everyday Life. Berkeley: University of California Press.

Cooper, Hall, C.,Timothy, M.C., J, Dallen. 2005. Shopping Tourism, Retailing and Leisure. : Channel View Publications.

Debord, Guy. 1967. The Society of the Spectacle. London: Rebel Press.

Gil. Sejarah Rock, http://my.opera.com/ HeavymetallizeR/blog/ diakses 2 Juni 2013.

Grange, Ashley la. 2005. Basic Critical Theory for Photographers. Oxford: Focal Press.

Hall, Stuart. 1997. Representation Cultural Representations and Signifying Practices. London, Thousand Oaks, dan New Delhi: Sage Publications.

Indie yang Ngga' Independen, http:// simphonymusic.com/opini/indieyang-nggak-independen/ diakses 4 Juni 2013.

Jenkins, Richard. 2004. Membaca Pikiran Pierre Bourdieu. Bantul: Kreasi Wacana.
Kornberger, Martin. 2010. Brand Society: How Brands Transform Management and Lifestyle. Cambridge: Cambridge University Press.

List of Emo Artist, http://en.wikipedia.org/ wiki/List_of_emo_artists diakses 5 Juni 2013.

Lury, Celia. 2004. Brands: The Logos of the Global Economy. New York: Routledge.

Luvaas, Brent. 2009. Generation DIY: Youth, Class, and the Culture of Indie Production in Digital-Age Indonesia. Disertasi: University of California.

Luvaas, Brent. 2013. "Material Intervention: Indonesian DIY Fashion and the Regime of the Global Brand".Cultural Anthropology.Vol. 28 Issue 1.Hal.127-143.

Satriyo, Fathoni B. Sejarah Industri Clothing dan Distro, http://www.brainonlinestore.com/news/5/SejarahIndustri-Clothing-Distro diakses 2 Juni 2013.

Uttu. 2006. Distro: Independent Fashion Moves from Margin to Mainstream. http:// www.insideindonesia.org/featureeditions/distro diakses 1 Juni 2013.

Terima kasih kepada yang telah membantu memberi datanya kepada penulis:

Andre, manajer penjualan dan operasional Nimco,

Mas Slamet, si tangan kanan pemilik Fusion, 7 Souls, dan $\mathrm{RSCH}$,

Imam, manajer toko Nimco,

Si Ganteng Priam, penjaga toko 7 Souls,

Mas Arie, penjaga toko Fusion,

Ayu Shinta, syahabat KBM 2012, atas diskusi BBM malam-malamnya,

Dan mereka para penjaga toko distro di areal Demangan yang tak sempat saya tanyakan namanya. 